Finanse, Rynki Finansowe, Ubezpieczenia nr 4/2016 (82), cz. 2

\title{
Markowitz versus Foster-Hart - what is the difference between efficient portfolios and the Foster-Hart portfolio?
}

\author{
Marcin Halicki*
}

\begin{abstract}
Purpose - This publication has the task of presenting the relationship between the efficient portfolios lying on the efficient frontier with a portfolio which is built using the Foster-Hart risk measure. The aim of the derivative work is to indicate the direction for further research focused around the measure in the context of reducing investment risk.

Design/methodology/approach - In the publication the literature in the area of portfolio management was used, as well as the hypothetical data that is formed for the basis of theoretical discussion. The study used analytical methods, including the method of linear programming.

Findings - On the basis of the built portfolio based on the Foster-Hart measure and the developed efficient frontier it was stated that the measure has a completely different approach to the management of portfolios in relation to the model of Markowitz. It manifests itself primarily in the method of the risk measurement and its interpretation as well as in the portfolios' construction.

Originality/value - The method of building a portfolio was elaborated on by using the Foster-Hart measure and by showing its relationship with the constructed efficient portfolios based on the Markowitz model. Such a presentation in the literature cannot be found. The analysis thus has educational and practical values.
\end{abstract}

Keywords: measurement, risk, portfolio management, efficient frontier, diversification

\section{Introduction}

The issue of the selection of the risk management methods to support investment decision-making is one of the key issues discussed in the management of portfolios. The 20th century brought the evolution and development of such methods, and thus the profound changes in the functioning models of financial institutions involved in the investing of cash assets. At the core of this evolution is the theory of Markowitz (Markowitz 1952, pp. 77-91), which also is now the starting point for the analysis of portfolios constructed according to various criteria. The factor contributing to the development and dissemination of the risk management methods is the fact that the development of this theory, the risk of portfolios of financial institutions began to measure widely using the Markowitz portfolio selection model (Markowitz 1959). All this has created a mechanism that led to the formulation of a variety of risk measures. The evolution of these measures can be divided into 5 stages:

\footnotetext{
* dr Marcin Halicki, Uniwersytet Rzeszowski, Wydział Biologiczno-Rolniczy, e-mail: mhalicki@ur.edu.pl.
} 
- the risk measures developed prior to the presentation of the Markowitz portfolio selection model,

- the measure of risk based on the Markowitz Portfolio Theory,

- the measure of the risk rate of return based on the Single-index model,

- the VaR (Value at Risk) and derivative measures,

- the coherent risk measures.

Despite the transformations that have taken the concepts of risk measurement in quantitive finance, the Markowitz model is the most well-known and widely used, although in the past the problematic issue in the portfolio theory of Markowitz was a practical determination of an efficient set (efficient frontier). Currently, this problem has been solved, since his designation used linear programming. It cannot be missed with these two facts. First and foremost, the efficient set, which may seem attractive to investors, at the same time, exposes them to bankruptcy. Second, the measurement of portfolio risk using the standard deviation is groundless because the measure is not monotonic (Foster, Hart 2009, pp. 785-814).

The idea of the risk measurement for years has preoccupied the attention of theoreticians and practitioners of business, which is why an attempt was made to develop a new measure of risk that is monotonic and which may form the basis for the construction of portfolios that do not expose investors to the risk of bankruptcy. It is the risk measure of the Foster-Hart (Foster, Hart 2009, pp. 785-814), which is also objective and universal. In literature however, the relationship between portfolios built on this measure ${ }^{1}$ and the portfolios located on the efficient frontier has not been the subject of discussion. The indication of such a relationship, as well as its characteristics are the main purpose of the publication, in which there was not only used the study literature, but also the theoretical discussion based on calculations on the basis of hypothetical data.

\section{General characteristics of an efficient frontier (efficient portfolios) and the method of its construction}

Before the above mentioned relationship will be presented, first the most important aspects of an efficient frontier must be identified. Well, in the Markowitz model (Markowitz 1952, pp. 77-91) the risk investment assets and portfolios are measured by the variance of returns. It was indicated that this approach is wrong, however, it can, to some extent, determine the level of risk that, in the light of such measure, may be decreased through diversification. The efficient frontier can be defined as the image of a set of portfolios that provide the maximum return for each level of risk or minimal risk for any level of return (Reilly, Brown 2001, p. 375). Efficient portfolios are these efficient combinations that are lying on the frontier. found.

${ }^{1}$ These portfolios can be called the Foster-Hart portfolios, though in literature such determination could not be 
For the construction of efficient portfolios with the practical assumption that there is no short sale, one can use the method of linear programming, i.e. The model, taking advantage function of the theory of Markowitz. It consists of limiting conditions and the specific objective of the liner forms. These assumptions are used in order to get the best results of mathematical functions to the specific restrictive conditions (Chen, Liou, Huang 2012, p. 455). The mentioned conditions of linear programming, including the lack of a short sale, accept the formula (Halicki, Slusarczyk 2014, pp. 436-437), whose main ingredient is the objective function, and the result has to be maximized. It is expressed by the following equation:

$$
R_{p}=\sum_{i=n}^{n} w_{i} \times R_{i} \rightarrow \max ,
$$

where:

$R_{p}$ - is the expected rate of return on a portfolio consisting of selected assets to be maximized under certain restrictive conditions,

$w_{i}-$ is percentage share of the $\mathrm{i}$-th asset in the portfolio,

$R_{i}-$ is the expected rate of return on the investment asset.

$n-$ the number of assets in the portfolio.

The first limiting condition refers to the level of the portfolios' risk whose value is measured using generally Markowitz (Markowitz 1952, pp. 77-91). This value, determined in advance, must be possible with the data asset shares in their portfolios. This is due to the fact that the purpose of linear programming is getting the maximum return for a given level of risk. According to the presented principle, the first limiting condition takes the form of the following equation:

$$
S p=\sqrt{\sum_{i=1}^{n} w_{i}^{2} s_{i}^{2}+\sum_{i=1}^{n} \sum_{j=1}^{n} w_{i} w_{j} s_{i} s_{j} \rho_{i j}}=\propto, i \neq j,
$$

where:

$S_{p}-$ is the standard deviation of the portfolios (according to the theory of Markowitz), which is the measure of risk but at the assumed possible level should allow for the maximum return of the portfolios,

$s_{i}^{2}, s_{j}^{2}$ - are the variances of the $\mathrm{i}$-th ( $\mathrm{j}$-th) portfolio asset,

$\rho_{i j}-$ is the coefficient of correlation between the $\mathrm{i}$-th asset and $\mathrm{j}$-th asset in the portfolio.

The second constraint implies that the short sale of portfolio assets is not allowed, so the share of each of the assets held in the portfolio may not be less than " $0 \%$ " or greater than "100\%", thus:

$$
0 \leq w_{i} \leq 1 ; 0 \leq w_{j} \leq 1 \text { and } i \neq j .
$$


The third constraint applies to all the shares in the portfolio, the sum of which must always be " $100 \%$ ". This is expressed by the equation:

$$
\sum_{i=1}^{n} w_{i}+\sum_{j=1}^{n} w_{j}=1, i \neq j
$$

There is no need to explain that the method of linear programming has the task of carrying out calculations to maximize the rate of return under certain conditions. This may include giving up the short sale of shares, which is associated with a very high risk. For most assets it is not possible. To sum up this part of the work, the method of linear programming is a great tool that allows the construction of the frontier for efficient stocks selected by the investor. It shows indeed the best combination of portfolios that can be built, under certain conditions, however we must not forget about some of its aspects.

It was mentioned that the concept of risk measurement using the standard deviation is not correct, because the measure is not monotonic. In addition, the efficient frontier, though precisely defines the relationship of the expected rate of return to the level of risk, it does not present any portfolios that would not compromise investors to bankruptcy. With all this in mind, it is worth presenting a different monotone risk measure that allows for the construction of the portfolio (or portfolios) that do not expose an investor to the risk of bankruptcy. The measure of Foster-Hart, as the discussion is addressed to it, is not often studied. Moreover, in literature one can not find a study devoted to the comparison of efficient frontier built on the model of the Markowitz portfolio, also built on the basis of the above-mentioned measure. Such a comparison should therefore be made, but first one needs to make a general characterization of the measure.

\section{General characteristics of the Foster-Hart risk measure}

The Foster-Hart measure has many advantages. These include: monotonicity, objectivity (Foster, Hart 2009, pp. 785-814), versatility and the ability to identify very risky investments which could lead to the bankruptcy of the investor. One can not miss the fact that it ignores the objectives and usefulness of investors (Bali, Cakici, Chabi-Yo 2012, p. 18) and does not depend on any parameters ad hoc. In addition, this measure brings important details in the development area of portfolios' management of financial instruments on the grounds that it takes into account the possibility of the investor's bankruptcy and may be regarded as a dynamic measurement of the risk (Hellmann, Riedel 2015, pp. 66-70). These properties may contribute to the fact that this measure will be more and more often the subject of scientific research focused on the analysis of the portfolio. 
The Foster-Hart risk measure takes the form of the following formula (for investment, “g”):

where:

$$
E\left[\log \left(1+\frac{1}{R(g)} g\right)\right]=0,
$$

$g \quad-$ means the result of the investment, so the income generated by the investment with a certain probability at the end of the investment period,

$R(g)$ - is the critical value of wealth (property) of the investor and the measure of investment risk "g". It can be easily noticed that the Foster-Hart formula treats $\mathrm{R}(\mathrm{g})$ as the unknown, because the probability and income must be specified.

The Foster-Hart formula is cognitively interesting because it allows calculating the value of $\mathrm{R}(\mathrm{g})$, which is the critical value of the current wealth of the investor who is interested in investments with fixed income and certain probabilities. The result of the equation of the Foster-Hart is interpreted by taking into account the relationship of $\mathrm{R}(\mathrm{g})$ with the current level of the investor's wealth. Therefore, two cases are possible:

- $\mathrm{R}(\mathrm{g})$ is higher than the current level of wealth of the investor - the investment " $\mathrm{g}$ " is considered to be too risky, because in a long period of time it can lead the investors to bankruptcy,

- $\mathrm{R}(\mathrm{g})$ is equal to or lower than the current level of wealth of the investor - the investment is considered to be acceptable and causes an increase in the investor's wealth in the long term.

The role of the Foster-Hart formula is worth presenting on the basis of the analysis of a hypothetical share. The data needed for the application of the characterized formula is shown in Table 1.

\section{Table 1}

Data of the share analyzed in terms of the application of the Foster-Hart formula

\begin{tabular}{|c|c|c|c|c|}
\hline & Probability & & & \\
\hline \multirow{2}{*}{$\begin{array}{l}\text { The purchase price at the beginning } \\
\text { of the investment period }\end{array}$} & $100 \%$ & & & \\
\hline & USD 900 & & & \\
\hline \multirow{2}{*}{$\begin{array}{l}\text { The sale price at the end of the } \\
\text { investment period }\end{array}$} & $25 \%$ & $25 \%$ & $25 \%$ & $25 \%$ \\
\hline & USD 45 & USD 936 & USD 1035 & USD 1926 \\
\hline Income from investments in a stock & USD -855 & USD 36 & USD 135 & USD 1026 \\
\hline
\end{tabular}

Source: own study. 
The data of the presented share make that the Hart-Foster equation takes the following form:

$$
\frac{1}{4} \log \left(1+\frac{-855}{R(g)}\right)+\frac{1}{4} \log \left(1+\frac{36}{R(g)}\right)+\frac{1}{4} \log \left(1+\frac{135}{R(g)}\right)+\frac{1}{4} \log \left(1+\frac{1026}{R(g)}\right)=0,
$$

hence

$$
R(g)=2,632.86
$$

From calculations carried out, it is clear that the minimum level of the investor's wealth who wants to invest their cash in the analyzed share should be at least USD 2,632.86. Moreover, if the assets will amount to USD 2,632.86 thoroughly, then according to the theory of Foster-Hart, they will be inert with respect to such investments, and therefore, may be willing to accept the theory, or reject it. However, each higher value of wealth will cause that the investor will be willing to accept the investment. One should not also forget that the investor in order to avoid bankruptcy, through the acquisition of one share, shall have at least USD $3,532.86$, or pay USD 900 and does not spend USD 2,632.86. It can easily be seen that for increasing the efficiency of the investment, the value of $\mathrm{R}(\mathrm{g})$ may be invested in the risk-free assets for a period of time equal to the duration of the investment in the data risky assets.

The analysis of Polish and foreign literature confirms that there is a need for a presentation of the relationship of the portfolios built on the Foster-Hart measure with the portfolios located on the efficient frontier, drawn up in accordance to the theory of Markowitz. Such a study can not be found anywhere and it may be desirable in order to develop the area of portfolio management.

\section{The efficient frontier and the Foster-Hart portfolio - a case study}

A suitable way of presenting relations of a portfolio built on the basis of the Foster-Hart measure with the portfolios located on the efficient frontier (prepared in accordance to the theory of Markowitz), is the analysis of a theoretical case study. Such an approach will identify the most important elements of this relationship, as well as the understanding of the presented material, which in the literature cannot be found. The study of the article assumes the following conditions:

- a hypothetical capital market offers only 10 shares, and therefore the portfolios are made up of these 10 shares,

- all shares with equal probability, equal to $50 \%$, may be sold at a fixed amounts at the end of the period of investment,

- the coefficients of correlation between these shares (the number is 45) are equal and are 1 , 
- on the investment one can allocate USD 10,000,000, but a part of that amount must be earmarked for protection from bankruptcy,

- for a single share one allocates USD 1,000,000 (assuming that funds are equally allocated for the purchase of individual stocks, and of this amount, as indicated above, is spent on protection against bankruptcy, because $R(g)$ is calculated separately for each share and not for the portfolio with a value of USD 10,000,000),

- in the course of the investment, no portfolio realignment is made,

- the return on risk-free is $1.5 \%$, which cannot be given and borrow at the interest rate,

- short selling is not possible.

The key data on the hypothetical shares, which have been developed for the use in calculations, are presented in Table 2.

Table 2

Highlights of shares which are included in the portfolio

\begin{tabular}{lllll}
\hline \multirow{2}{*}{ Share number } & \multicolumn{2}{l}{ Sale price (USD) } & $\begin{array}{l}\text { Purchase price } \\
\text { (USD) }\end{array}$ & R(g) (USD) \\
\cline { 2 - 5 } & Scenario 1 & Scenario 2 & 1,000 & 2,700 \\
1 & 1,045 & 45 & 120 & 675 \\
2 & 255 & 7.5 & 18 & 54 \\
3 & 28.8 & 9 & 50 & 189 \\
4 & 87.8 & 18.50 & 300 & 540 \\
5 & 408 & 210.00 & 270 & 513 \\
6 & 372.6 & 184.50 & 180 & 27 \\
7 & 185.4 & 175.50 & 40 & 3.78 \\
8 & 40.756 & 39.37 & 10 & 4.32 \\
9 & 10.864 & 9.28 & 700 & 216 \\
10 & 743.2 & 664.00 & & \\
\hline Probability & 0.50 & 0.50 & & \\
\hline $\begin{array}{l}\text { The rate of return of risk } \\
\text { free assets }\end{array}$ & $1.5 \%$ & & \\
\hline The coefficients of corre- & & & \\
lations between selected \\
shares
\end{tabular}

Source: own study.

According to the lack of significant influence of the manner of the undertaken calculations and for the sake of the transparency of the results, the work does not show any calculations that are required for the construction of the efficient frontier and the Foster-Hart portfolio. It should be noted; however that using, in the work the characterized method of linear programming, one received data, which are necessary for the preparation of the efficient frontier. It has been shown in Figure 1. 


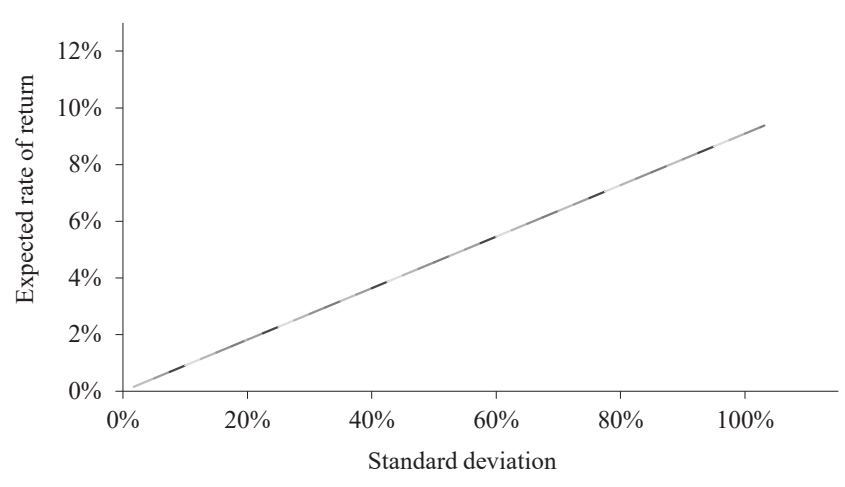

Figure 1. The efficient frontier drawn up on the basis of the Markowitz model using linear programming

Source: own study.

The efficient frontier is the subject of many studies, so it does not need to be devoted much attention. Since the work assumes that the correlation coefficients are equal and reach a value of 1, it contributed to obtaining the efficient frontier as a straight line. As it is well known in practice this form does not usually exist. It was also assumed that a short sale is not permitted, and therefore the maximum return portfolios which are on the verge can not tend to infinity. On the basis of calculations, it was found that:

- the minimum risk level of the portfolio lying on the frontier, measured according to the Markowitz rule, is $1.73 \%$ at the maximum expected rate of return equal to $0.16 \%$,

- the maximum level of portfolio risk lying on the frontier is $103.13 \%$, with the maximum expected rate of return equal to $9.38 \%$.

Using the measures of Foster-Hart in the process of portfolio construction it allowed obtaining relevant information, which the Markowitz model and the efficient frontier are not able to generate. It was calculated in fact where the amount may be invested in equities that automatically points to the value of cash, which can not be spent (at most the cash can be invested in risk-free assets). The quantitative research allowed obtaining the following results:

- in the shares one must invest $48.28 \%$ of USD $10,000,000$,

- in the risk-free assets one must invest $51.72 \%$ of USD $10,000,000$,

- the Foster-Hart measure allowed to build only one Foster-Hart portfolio, which is characterized by the expected rate of return equal to $1.79 \%$ and the level of risk (as measured according to the formula of Markowitz) with the value of $19.64 \%$,

- the Foster-Hart measure is a tool reflecting the risks of individual investments; therefore, diversification in terms of this measure must rely on the fact that the set of investment should be treated as a single investment with a large number of possible distributions with different values of probability. 
To enrich the discussion, the author determined the position of the made Foster-Hart portfolio in the coordinate system, taking into account the investment in risk-free assets. This allows for a better presentation of the relationship of the portfolio (which is the only combination of investments) with the efficient frontier, which reflects the large array of investment. This position is shown in Figure 2.

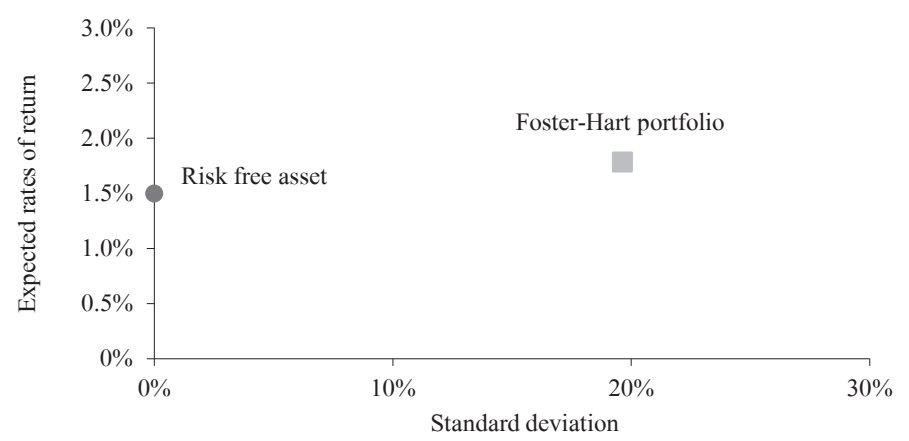

Figure 2. The portfolio built on the basis of the Foster-Hart measurement and its location in a coordinate system with investment in risk-free assets

Source: own study.

The analyses show that the Markowitz approach, shown in the form of the efficient frontier, is entirely different from the theory of Foster-Hart, which focuses on individual, risky investments. The main differences are shown in Table 3.

As it is shown in Table 3, in the conducted analysis of both concepts the author based conclusions on four factors which are designed to capture the most important differences. With regard to them, on the first plan one should draw the conclusion that the concept of Markowitz, constituting the basis for the construction of the efficient portfolios, is quite different from the theory of Foster-Hart. This difference is expressed in the process of risk assessment, and its interpretation. The efficient portfolios, for the way they are built, are different combinations of investments than the Foster-Hart portfolio. As it was mentioned, it is the only combination with specific weights of assets that a given value of $\mathrm{R}(\mathrm{g})$ should not, in theory, expose the investor to bankruptcy. That most important feature, exposed in the work, distinguishes it from the portfolios built on any other investment models. Due to the lack of diversification, one should analyze the risk of the Hart Foster for treatment of the portfolio as a single share. Then it may be found that this measure also allows the investor to reduce the risk, expressed with the value of $\mathrm{R}(\mathrm{g})$. But it cannot be said unequivocally that lowering this value is correlated with the reduction of risk measured using the Markowitz model. Additionally, it can be also checked whether this measure is in fact objective, since in the literature there are views that objectivity is not its feature (Demertzis 2010, pp. 1-6). 
Table 3

The most important differences between the concept of efficient frontier and the Foster-Hart portfolio

\begin{tabular}{|c|c|c|}
\hline Element & $\begin{array}{l}\text { Efficient frontier } \\
\text { (efficient portfolios) }\end{array}$ & Foster-Hart portfolio \\
\hline $\begin{array}{l}\text { Risk and its } \\
\text { measurement }\end{array}$ & $\begin{array}{l}\text { The risk is measured and based } \\
\text { on the Markowitz model is expres- } \\
\text { sed in percentages. It is assumed that } \\
\text { the risk of a single overall merit can } \\
\text { be measured by standard deviation, } \\
\text { which is an incorrect assumption. }\end{array}$ & $\begin{array}{l}\text { The risk reflected in numerical value is expressed in the } \\
\text { currency in which the investment generates the income. } \\
\text { Therefore, the Foster-Hart portfolio has a quota level } \\
\text { of risk, which also shows the minimum amount that will } \\
\text { cushion the possible bankruptcy. The risk measure is } \\
\text { objective, universal and monotone. }\end{array}$ \\
\hline $\begin{array}{l}\text { Diversifica- } \\
\text { tion and risk } \\
\text { reduction }\end{array}$ & $\begin{array}{l}\text { Diversification is possible by } \\
\text { building portfolios with different } \\
\text { weights of investment assets. Taking } \\
\text { into account the value of the index } \\
\text { of correlation between pairs } \\
\text { of assets, the risk may be reduced. } \\
\text { The combinations with the lowest } \\
\text { possible risks are on the efficient } \\
\text { frontier. }\end{array}$ & $\begin{array}{l}\text { The risk measure of Foster-Hart allows making a portfo- } \\
\text { lio, if the value of } \mathrm{R}(\mathrm{g}) \text { shall be calculated for each asset } \\
\text { separately. This means the lack of diversification and } \\
\text { risk reduction. It is not important whether the risk will } \\
\text { be measured by the Markowitz model, or by an index } \\
\mathrm{R}(\mathrm{g}) \text {. The only possibility of diversification occurs if the } \\
\text { portfolio was treated as a single investment. Then, for } \\
\text { each combination of investment, differing with weights } \\
\text { of individual assets, } \mathrm{R}(\mathrm{g}) \text { would be calculated separate- } \\
\text { ly. Thus, the investor would choose such a combination } \\
\text { for which the value of } \mathrm{R}(\mathrm{g}) \text { would be the lowest. }\end{array}$ \\
\hline $\begin{array}{l}\text { Investor's } \\
\text { bankruptcy }\end{array}$ & $\begin{array}{l}\text { Efficient portfolios do not take into } \\
\text { account the possibility of the inve- } \\
\text { stor's bankruptcy. }\end{array}$ & $\begin{array}{l}\text { The Foster-Hart portfolio takes into account the possi- } \\
\text { bility of the investor's bankruptcy, but its composition } \\
\text { with the value of } \mathrm{R}(\mathrm{g}) \text { in theory reduces the probability } \\
\text { of the bankruptcy. }\end{array}$ \\
\hline $\begin{array}{l}\text { Combinations } \\
\text { of investment }\end{array}$ & $\begin{array}{l}\text { All combinations of the least risky } \\
\text { investment at the maximum possible } \\
\text { rate of return are located on the effi- } \\
\text { cient frontier, therefore the investor } \\
\text { taking into account his preferences, } \\
\text { may voluntarily choose one of them. }\end{array}$ & $\begin{array}{l}\text { The Foster-Hart portfolio is the only combination that } \\
\text { can be selected by an investor to avoid bankruptcy. } \\
\text { Thus, as the investor would be able to choose any com- } \\
\text { bination of investment, he/she must have the extra cash, } \\
\text { beyond that already allocated for the project. Then these } \\
\text { additional resources can be allocated for investments } \\
\text { in risk-free assets, which of course will reduce the profi- } \\
\text { tability of the entire investment project, while reducing } \\
\text { the risk (no matter how it is measured). }\end{array}$ \\
\hline
\end{tabular}

Source: own study.

\section{Conclusions}

More than fifty years since the birth of the area of portfolio management contractually bound with the "Portfolio Selection" publication by H. Markowitz in 1952, may lead to reflect on the current state of knowledge in the field of the measurement of the investment risk and diversification. This type of reflection which is mainly empirical, is currently still visible, and despite the emergence of a variety of risk measures, still arouses strong reactions. On the theoretical level, it is enough to mention the discussions about the false assumption that the risk of the asset can be measured by the standard deviation (Foster, Hart 2009, pp. 785-814) or that the measure Var (not coherent) depends on the parameters 
of an ad hoc (Halicki 2016, pp. 594-607). These kinds of circumstances, combined with the nature of the field of portfolio management, transfer well to the realm of a practical sphere. This, then, focused on acquiring customers and offering them a portfolio of high rates of return and a low-risk as possible, is interested in new metrics that will effectively support the portfolio management process. These include the Foster-Hart measure.

The role of this new measure in the process of portfolio management in the literature has already been emphasized (Halicki 2016, pp. 594-607). This is due to the fact that this measure is monotonic and may form the basis for the construction of portfolios that do not expose investors to the risk of bankruptcy. Moreover, it is also objective and universal. In the literature one cannot find a study showing the relationship of portfolios constructed on the basis of this measure with portfolios located on an efficient frontier. For this reason, the article attempts to present this relationship and to evaluate how much the efficient wallets differ from the portfolio built on the basis of the Foster-Hart measure. Understanding this relationship, based on the construction of portfolios, consisting of ten hypothetical shares, extends the knowledge of the management of portfolios. At the same time, the presented analyses which are characterized by the cognitive value also have a practical value as the discussed cases show how to make portfolios based on the Foster-Hart model, and suggest how to define the part of the savings allocated to investments in risk-free assets to avoid bankruptcy. Finally, it is worth mentioning what research should be conducted in the analysis of this measure. These should include three aspects. First, one should check whether it is objective. Secondly, there should be developed a way to diversify the portfolio with its use. Thirdly, hedge funds should use it to minimize the risk and check its effectiveness in this respect, as in the period of optimism in the stock market, investors are interested in the reduction of systematic risk (Racicot, Théoret 2016, p. 59).

\section{References}

Bali T.G., Cakici N., Chabi-Yo F. (2012). Does Aggregate Riskiness Predict Future Economic Downturns. Fisher College of Business WP, 2012-03-009.

Chen B., Liou F.-M., Huang C.-P. (2012). Optimal Financing Mix of Financially Non-Viable Private-Participation Investment Project with Initial Subsidy. Inzinerine Ekonomika-Engineering Economics, 23 (5).

Demertzis M. (2010). An Operational Measure of Riskiness: A Comment. De Nederlandsche Bank-Working Paper, $262,1-6$.

Foster D.P., Hart S. (2009). An Operational Measure of Riskiness. Journal of Political Economy, 117 (5), $785-814$.

Halicki M. (2016). Foster-Hart measure as a suport element for the portfolio management process. "Stan i perspektywy rozwoju nauk o zarządzaniu”. Toruń: Wyd. Dom Organizatora.

Halicki M., Ślusarczyk B. (2014). Procesy globalizacji i internacjonalizacji a zarzadzanie portfelem. „Rozwój organizacji i regionu wyzwaniem dla ekonomii i nauk o zarządzaniu”, Lublin-Toruń.

Hellmann T., Riedel F. (2015). A Dynamic Extension of the Foster-Hart Measure of Riskiness. Journal of Mathematical Economics, 59, 66-70.

Markowitz H. (1959). Portfolio Selection - Efficient Diversification of Investments. New York: John Wiley \& Sons.

Markowitz H. (1952). Portfolio Selection. The Journal of Finance, 7 (1), 77-91.

Racicot F.-É., Théoret R. (2016). Macroeconomic Shocks, Forward-Looking Dynamics, and the Behavior of Hedge Funds. Journal of Banking \& Finance, 62, 59.

Reilly F.K., Brown K.C. (2001). Analiza inwestycji i zarządzanie portfelem, T. I. Warszawa: PWE. 


\section{MARKOWITZ VERSUS FOSTER-HART - CZYM RÓŻNIĄ SIĘ PORTFELE EFEKTYWNE OD PORTFELA FOSTERA-HARTA?}

Streszczenie: $\mathrm{Cel}$ - Niniejsza publikacja ma zadanie prezentację relacji pomiędzy portfelami leżącymi na granicy efektywnej z portfelem zbudowanym przy użyciu miary Fostera-Harta. Celem pochodnym pracy jest wskazanie kierunku dalszych badań skupionych wokół tej miary w kontekście redukcji ryzyka inwestycyjnego.

Metodologia badania - W publikacji wykorzystano literaturę z obszaru zarządzania portfelami, a także dane hipotetyczne, które stanowią bazę dla rozważań o charakterze teoretycznym. W pracy zastosowano metody analityczne obejmujące metodę programowania liniowego.

Wynik - Na podstawie portfela zbudowanego w oparciu o miarę Fostera-Harta i opracowanej granicy efektywnej stwierdzono, że miarę tą cechuje zupełnie odmienne podejście do zarządzania portfelami w stosunku do modelu Markowitza. Przejawia się to głównie w sposobie pomiaru ryzyka, oraz jego interpretacji i budowie portfeli.

Oryginalność/wartość - Opracowano sposób budowy portfela używając miary Fostera-Harta a także pokazano jego relację z portfelami efektywnymi skonstruowanymi w oparciu o model Markowitza. Takiej prezentacji w literaturze nie można odnaleźć. Przedstawione analizy mają więc wartość poznawczą i praktyczną.

Słowa kluczowe: miary; ryzyko; zarządzanie portfelami; granica efektywna; dywersyfikacja

\section{Citation}

Halicki M. (2016). Markowitz versus Foster-Hart - what is the difference between efficient portfolios and the Foster-Hart portfolio? Finanse, Rynki Finansowe, Ubezpieczenia, 4 (82/2), 121-132. DOI: 10.18276/ frfu.2016.4.82/2-09. 